\title{
Pozitif Bir Bilim Olarak Psikoloji
}

\author{
Psychology As A Positive Science \\ Dr. Öğr. Üyesi Hamdi KORKMAN ${ }^{1}$
}

\begin{abstract}
Özet
Psikoloji tarihine bakıldığında psikolojinin bilim olma kimliğine, fizik ile kurduğu bağ sayesinde ulaştığı görülür. Müller'den başlayarak, Helmholtz, Weber, Fechner ve en nihayet Wundt'a kadar uzanan yolda temel düşünce, bilincin fizik kanunlarını tespit etmek idi. Bu düşüncenin altında yatan ise, Newton'un kanunlarının felsefede ele alınan temel konulara da uygulanabileceği düşüncesiydi. Soyut bir mekanizma olan zihin ile somut bir mekanizma olan bedenin etkileşip etkileşmediklerini, etkileşiyorlarsa bunun nasıl gerçekleştiğini çözmeye yönelik olarak yürütülen zihin-beden sorunu tartışması, felsefede uzun zamandır sürmekteydi. Descartes'in ele aldığı ruh (zihin)-beden sorununu fiziğin ilkelerini kullanarak açılama düşüncesi, psikolojinin bilim olmasında önemli bir rol oynamıştır. $\mathrm{Bu}$ düşünce ile yola çıkan psikolojinin, sosyal bilim safına kayması fazla uzun sürmemiştir. Duyum, algı, bellek, öğrenme vb. gibi bilincin öğelerini teşkil eden konuların pozitif bilimlerin yöntemleriyle çalışılmasındaki zorluk, bu durumun başlıca nedeni olmuştur. Bugün psikoloji artık bir yol ayrımındadır ve tercihini sosyal bilimden yana mı, yoksa pozitif bilimden yana mı kullanacağına karar vermelidir. Bu karar, psikolojinin bugününü ve yarınını şekillendirmede çok önemli bir yere sahip olacaktır. Bu düşüncelerden hareketle mevcut çalışmada, psikolojinin kısa bir tarihsel arka planı verilerek, psikolojinin günümüzde ve gelecekteki durumunun sosyal bilim olarak $\mathrm{m}$ yoksa pozitif bilim olarak $\mathrm{m}$ şekillenmesi gerektiği tartışılmıştır.
\end{abstract}

Anahtar Sözcükler: Zihin-beden sorunu, duyum, algı, biliş, sosyal bilim, psikoloji, pozitif bilim

Makale Türü: Derleme

\begin{abstract}
When the history of psychology is observed, it appears that psychology's identity of being a science has been achieved through its connection with physics. Starting from Müller, Helmholtz, Weber, Fechner, and finally, until Wundt, the basic idea was to determine the physical laws of conscience. Underlying this thought was the belief that Newton's laws could be applied to the fundamental issues dealt with in philosophy. The discussion of the mind-body problem, which was intended to solve whether the mind, a non-physical mechanism, interacts with the body as a concrete mechanism, and how this interaction occurs, has long been on the agenda in philosophy. The idea of explaining the spirit (mind)-body problem of Descartes using the principles of physics has played an important role in psychology's becoming a science. The shift of the psychology that came out with this thought to the side of social science did not last long. The difficulty in working with the methods of positive sciences, which constitute conscience items such as sensation, perception, memory, learning,etc. has been the main cause of this situation. Today, psychology is now at a crossroad and should decide whether to favour social science or positive science. This decision will have a very important place in
\end{abstract}

\footnotetext{
1 Afyon Kocatepe Üniversitesi, Sandıklı Uygulamalı Bilimler Yüksek Okulu, hkorkman@aku.edu.tr, Orcid ID: https://orcid.org/0000-0001-6025-9696
} 
shaping the present and future situation of psychology. Moving on from these thoughts, this study will be presenting a brief historical background of psychology and whether the present and the future situation should be shaped as social science or as positive science will be argued.

Keywords: Mind-body problem, sensation, perception, consciousness, social science, positive science

Paper Type: Review

Giriş

Johannes Müller, Helmholtz, Weber ve Fechner gibi bilim insanlarının çalışmalarının psikolojinin bilim olmasında çok önemli bir katkısı ve etkisi vardır. Bu bilim insanlarının amac1, Newton fiziğini fizyolojiye uygulamaktı ve temel soru: "Eğer evren fizik ilkelere dayanarak açıklanabiliyorsa, insan bedeni ve zihni de bu şekilde açılanamaz mı?" sorusuydu. Bu bağlamda sinir sistemi ve beyin üzerine çalışmalar yapılmaya başlanmıştı. $\mathrm{Bu}$ çalışmalar, kısa bir süre sonra psikolojinin doğuşuna zemin hazırlamıştır. Nitekim, Wundt'un çalışmasında "psikolojinin fiziği” kavramını kullanması, fiziğin psikoloji üzerindeki etkisini net bir şekilde göstermektedir. Yani aslında psikoloji, pozitif bilim olma amaciyla yola çıkmıştır. Fakat bellek, öğrenme, dil, duyum, algı vb. gibi üst düzey bilişsel fonksiyonları pozitif bilimlerin yöntemleri ile araştırma konusundaki zorluklar psikolojiyi sosyal bilim safına doğru kaydırmıştır. $\mathrm{Bu}$ çalışma, psikolojinin doğası gereği sosyal bilim olamayacağını, yazgısının pozitif bilim safına kaymak olduğunu gösterebilmeyi amaçlamaktadır. Bu bağlamda öncelikle psikoloji tarihine bir göz atmak faydalı olacaktır.

Psikoloji tarihi konusundaki alanyazın incelendiğinde, psikolojinin başlangıcının Descartes'in ruh-beden ikilemi üzerine geliştirdiği düşüncelere dayandırıldığ 1 görülmektedir (Boring, 1950; Karakaş, 2003; Karakaş ve Bekçi, 2003; Karakaş, Bekçi ve Irak, 2003; Karakaş, Kafadar ve Bekçi, 2001; Özakpınar, 2013; Schultz ve Schultz, 2007). Descartes, insanın ruh ve beden olmak üzere iki farklı yapıdan oluştuğunu ileri sürmüş ve bedeni bir "otomata" (makine) olarak, ruhu ise düşünme, algılama ve isteme gibi bir takım yollarla bedeni etkileyerek hidrolik sistemi harekete geçiren bir yapı olarak düşünmüş̧ür. Buna göre, beden tıpkı bir makine gibi çalışmaktadır. Dolayısıyla ruh bedeni beden de ruhu etkilemektedir (Descartes, 2014). Descartes, ruh ve bedenin etkileşiminin beyindeki 'corpus pinealis'te (beyin epifizi) gerçekleştiğini ileri sürmüştür. Descartes'in bu savının temelinde, 'corpus pinealis' in çift taraflı olmaması yatmaktadır. Ruh-beden etkileşimini mekanik yoldan açıklamaya çalışan Descartes, sinir tüplerindeki hayvansal ruhların (animal spirits) hareketlerinin 'corpus pinealis'te bir baskı oluşturmasıyla birlikte ruhun duyumları ürettiğini düşünmüştür (Boring, 1950; Karakaş ve Bekçi, 2003; Karakaş, Kafadar ve Bekçi, 2001; Schultz ve Schultz, 2007).

Churchland (2012) Descartes'in, bedeni mekanikçi felsefe ile açıklayabiliyorken zihni bu felsefe ile açıklayamamasının onu ruh-beden sorununa düalist yaklaşmaya mecbur bıraktığını belirtir. Churchland'a göre Descartes, bu nedenden ötürü zihni açıklayabilmenin yolunun iç gözleme yönelmek olduğunu ve insanın özünde, düşünen bir tözden başka bir şey olmadığını saptayabileceğini düşünmüştür.

Descartes'in otomata düşüncesinin temelinde, Avrupa'da on altıncı ve on yedinci yüzyılda fizik biliminde yaşanan gelişmeler yer almaktadır. Galileo'nun düşünceleri ile başlayıp Coppernicus, Tycho Brahe ve Kepler ile devam eden ve en nihayetinde Newton ile 
önemli bir noktaya ulaşan fizik bilimi, evrenin mekanik ilkelere göre çalıştığını ortaya koymaya başlamıştı. Evrenin mekanik ilkelere göre işleyen bir yapı olduğu fikri, felsefe ve bilim dünyasında önemli bir dönüm noktası oldu. Descartes'in otomata fikrinin altyapısında da bu yaklaşım vardı. On yedinci yüzyılda evrenin büyük bir makine olarak tasavvur edilmesi "mekanik ruh" (the spirit of mechanism) kavramını doğurdu. Saatin icadı, bu düşünceyi destekleyen gelişmelerden en önemlisi oldu. Boyle, Kepler ve Descartes gibi önemli düşün ve bilim insanları, "evrenin büyük bir saat düzeneği”" gibi çalıştığı fikrini şiar edinmişlerdi. Evrenin saate benzetilmesi, indirgemecilik (reductionizm) düşüncesinin bir ürünüydü. Karmaşık, dolayısıyla açıklanması zor, bir yapıyı basit ve anlaşılabilir bir yapıya benzeterek açıklama düşüncesine dayanan indirgemecilik, düşünce ve bilim dünyasında önemli bir yere oturdu (nitekim günümüzde bile psikoloji biliminde bilişsel sistemin anlaşılabilmesi için beyin, bir bilgisayara benzetilmektedir). On yedinci yüzyılda bilimde meydana gelen gelişmeler sayesinde ortaya çıkan mekanik ruh ve indirgemecilik düşüncesinin yanı sıra belirlenimcilik (determinizm) de önemli bir düşünce haline geldi. Evren bir saat gibi mekanik ilkelere göre çalışıyorsa, o zaman bu saatin çalışma ilkeleri anlaşıldığında evrenin de nasıl çalıştığı anlaşılabilirdi. Nasıl ki bir saatin parçaları arasındaki ilişkiler anlaşıldığında saatin çalışma ilkesi anlaşılıyorsa, doğanın ve evrenin parçalara ayrılması ve bu parçalar arasındaki neden sonuç ilişkilerinin çözümlenmesi de doğanın ve evrenin çalışma ilkelerinin anlaşılmasına yol açabilirdi. Bu düşüncenin oluşumunda en başat rol, Newton'un çalışmalarına ait idi. Newton'un kütle çekim kanunları, hareket üzerine binlerce yıldır devam eden tartışmaları sonlandırmıştı. Bu durum, felsefede binlerce yıldır devam eden tartışmaların da fizik bilimi ile sonlandırılabileceği düşüncesini doğurdu. Evren mekanik ilkelere göre işliyorsa, pekâlâ insan bedeni de mekanik ilkelere göre işliyor olabilirdi. Evren düzenli, tahmin edilebilir nitelikte, gözlenebilir ve ölçülebilir bir makineye benziyorsa, insan bedeni de aynı şekilde olamaz mıydı? Descartes'in ve La Mettrie'nin insan bedenini bir otomata olarak düşünmelerinin nedeni işte bu ön kabuldü. Bu mekanistik, indirgemeci ve deterministik anlayış, fizyolojinin ve tabi ki dolayısıyla psikolojinin ortaya çıkmasındaki temel belirleyici anlayış olmuştur. Daha önceleri ruha atfedilen duyum ve algı gibi kavramların bedenin işleyiş tarzıyla ilişkili olabileceği düşüncesi, psikolojinin bir bilim olma yoluna girmesinde temel bir rol oynamıştır. Burada ilk ve en temel rol Descartes'e aittir. Descartes, ruh-beden sorununa fizyolojik-psikolojik düalizm çerçevesinde yaklaşan ilk filozof olduğundan soyut bir kavram olarak ele alınan ruh kavramını, aklın ve zihinsel işlevlerin araştırılmasına doğru yönlendirmiştir. Descartes'in bu açılımı, ruha atfedilen kavramların metafizik analizlerden sıyrılıp nesnel gözlemlere doğru yönlenmesinin önünü açmıştır (Boring, 1950; Can, 2009; Karakaş, 2003; Karakaş ve Bekçi, 2003; Karakaş, Bekçi ve Irak, 2003; Karakaş, Kafadar ve Bekçi, 2001; Schultz ve Schultz, 2007). Ayrıca on altıncı ve on yedinci yüzyıllarda anatomistler, beyinde farklı işlevleri yerine getiren bölümler olduğunu gözlemlemişler ve anatomi alanyazınına serebrum, serebellum ve medulla oblongata kavramlarını kazandırmışlardır (Tarlacı, 2009a).

Descartes'in ruh-beden sorununa mekanistik, indirgemeci ve deterministik yaklaşımının yanı sıra Darwin'in evrim kuramının da psikolojinin bilim olmasında önemli bir payı olmuştur. İnsan davranışlarının anlaşılmasında hayvan davranışları üzerine yapılan gözlemlerin kullanılması fikrinin temelinde evrim kuramı yer almaktadır (Özakpınar, 2013; Schultz ve Schultz, 2007).

Fizik bilimindeki büyük atılımın matematik sayesinde gerçekleşmesinin biyoloji ve fizyoloji gibi diğer alanlara da önemli yansımaları olmuştur. Nitekim psikolojinin bir bilim 
olma yolunda ilerlemesinde çok önemli katkıları olan Müller, Helmhotz, Weber ve Fechner gibi bilim insanları duyum ve algı gibi konuları, fizyoloji, fizik ve matematiği kullanarak ölçmeye çalışmışlardır (Karakaş ve Bekçi, 2003; Karakaş, Kafadar ve Bekçi, 2001; Schultz ve Schultz, 2007).

Newton'un bilim dünyasına yaptığı diğer önemli bir etki ise Galvani üzerinde olmuştur. Galvani'nin sinir iletimini elektriksel ve kimyasal mekanizmalarla açıkladığı kuramının temelinde Newton'un etkisi vardır. Bu kuram, hareket ve duyusal işlevlerin aynı sinir lifleri üzerinden taşındığı üzerinde durmaktadır (Tarlacı, 2009a). Galvani, 1791'de kurbağa siyatik sinirine elektriksel uyarım vererek yaptığı deney ile kurbağa bacaklarının içsel elektrik sayesinde hareket ettiği sonucuna varmıştır. Bu deney, Galvani'nin biyoloji, elektrik ve hareket etme (canlılık) arasındaki bağlantıyı gösteren ilk kişi olmasını sağlamıştır (Bresadola, 1998; Kipnis, 1987; Koob, 2011; Piccolino, 1997; Tarlac1, 2009a). Galvani'nin bu deneyi, ilerleyen yıllarda nöronal iletinin elektriksel bir faaliyet olup olmadığı konusunda yapılan araştırmalara öncülük etmiştir (Koob, 2011; Piccolino, 1997).

Galvani’nin kurbağalar üzerinde yaptığı çalışmalarda elektriğin fiziksel harekete yol açtığını gözlemlemesi, fiziğin fizyoloji ile bağını kurma yolunda önemli bir gelişme olmuştur. Du Bois-Reymond'un sinirlerin elektrik ilettiği fikrini savunması ona "aksiyon potansiyeli" kavramının babası olma ünvanını kazandırmıştır. Zaten daha önceleri Remak'ın çalışmaları sayesinde, aksonların başlangıç yerlerinin nöronlar olduğu kanıtlanmıştı. Edgar Douglas Adrian (Lord Adrian), 1912'de bütün nöronların aksiyon potansiyeli denilen elektrik enerjisini aynı şekilde ilettiğini göstermiş bunun yanı sıra sinirsel uyarım şiddeti bir süre aynı şekilde devam ettiğinde sinirsel deşarj frekansının azalması sonucunda duyumun zayıfladığını bulgulamıştır. Bu bulgu sayesinde, duyusal adaptasyon denilen psikolojik olgunun nörofizyolojik temeli olduğu görülmüştür. Diğer yandan G. Fritsch ve E. Hitzig, düşüncenin üretilmesinin nöronlar sayesinde oluştuğunun ve düşüncelerin serebral korteksten çıkış aldığının anlaşılmasını sağlamıştır. Onların köpekler üzerindeki çalışmaları, korteksin elektrikle uyarılması sonucunda motor kontrolün gri maddeden kaynaklandığını, korteksin uyarıldığı tarafın ters yönündeki vücut bölgelerinde hareket meydana geldiğini ve korteksin değişik bölümlerinin vücudun farklı eylemlerinden sorumlu olduğunu göstermiştir. $\mathrm{Bu}$ bulgular, maymunlar üzerinde yapılan deneylerle de doğrulanmıştır. Fizyoloji alanında ortaya çıkan tüm bu gelişmeler, zihinsel süreçlerin anlaşılmasına doğru giden yola 1şık tutmuştur (Andreassi, 1995; Brazier, 1988; Koob, 2011; Ochs, 2004; Özakpınar, 2013). Ayrıca G. Fritsch ve E. Hitzig, yaptıkları deneylerle beyinde belirli kortikal alanların elektriksel olarak uyarılmasının kas hareketlerine neden olduğunu bulgulamışlardır (Schultz ve Schultz, 2007). G. Fritsch ve E. Hitzig, bu deneylerle Rolando yarığının ön tarafının korteksin bedenin hareketlerini yöneten bölgesi olduğunu göstermişlerdir (Taylor, 1967 ve Young 1970'den akt. Özakpınar, 2013).

Rudolf Virchow ile onun öğrencileri olan Otto Ditters ve Albreicht von Kolliker ilk kez nöronların eksiksiz çizimlerini yaptıktan sonra Robert Remak, öküzün sinir sistemini inceleyerek omurilikteki hücre yapısının liflere bağlı olduğunu göstermiştir. Bu keşif, beyin hücrelerinin lif şeklinde yayılan kuyruklarının bulunduğunu ortaya koyuyordu. Wilhelm Gottfried von Waldeyer, uzun çıkıntıları bulunan bu özel hücreleri tanımlamak için "nöron" terimini ortaya atmış ve bu terim kabul görmüştür. Camilio Golgi ve Santiago Ramòn y Cajal nöron üzerine yaptıkları araştırmalar ile öne çıkmış; Golgi, gümüş nitrat kullanarak nöronları ve nöronlardan uzanan kuyruksu uzantıları görüntülemeyi başardıktan sonra beyin 
hücrelerinin birlikte ve geçişli bir ağ gibi çalıştığını düşünmüştür. Cajal, Sigmund Exner'in beyindeki hücre iletiminin sadece nöron merkezli olduğu yolundaki çalışmasını temel alarak Exner'in kuramını geliştirmiştir. Cajal, bu sayede bir nöron doktrini geliştirmiştir ama sinir bilime katkıları bununla kısıtlı kalmamış nöronal morfoloji, haberleşme ve gelişim ile ilgili de önemli katkıları olmuştur. Bilginin depolanması ve işlenmesinde aktif olan tek yapının nöronlar olduğu konusundaki genel kabulün oluşmasında en önemli rol Cajal'a aittir (Azmitia ve ark. 2002; Clarke ve Jacyna, 1987; Finger, 1994; Koob, 2011; Shepherd, 1991; Zengeroğlu ve Nalçac1, 2015).

On yedinci yüzyllda mikroskobun keşfi sayesinde sinir sistemi üzerinde gözlem yapabilme imkânının ortaya çıkması bir dönüm noktası olmuş ve uzunca zamandır hüküm süren sinirlerde "ruh"ların dolaştığı fikrinin mikroskop sayesinde nihayet test edilebilmesi mümkün olmuştur. Nitekim, on yedinci yüzy1lın sonu on sekizinci yüzyılın başında Hollandalı bilim insanı Anton von Leeuwenhoek, sinir sistemini ilk kez mikroskop ile analiz etmiştir. On dokuzuncu yüzyılda mikroskopların gelişmesiyle birlikte, beynin hücrelerden oluştuğu anlaşılmıştır (Koob, 2011).

\section{Fizyoloji Alanında Yapılan Çalışmalar}

17.yy.'da Thomas Willis, beyindeki sinir ağlarının ve kan damarlarının yapısını incelemiş ve beynin işlevlerinin beyin ve beyinciğin görevi olduğunu ortaya koymuştur. Uyku ve uyanıklıktaki bilinç değişikliklerini fark ederek bu değişikliğin nedeninin beyin kabuğu ve hemen altındaki ak madde olduğunu ileri sürmüştür (Tarlacı, 2009a). Bu çalışma, bilincin beyin ile ilişkisini anlama yolunda ilk adımı teşkil etmesi önemlidir.

Willis'in çalışmasının ardından Jan Swemmerdan'ın Galenos'dan beri kabul gören hareketi düzenleyen merkezi organın kalp değil, beyin olduğunu yaptığ 1 deneyle ortaya koyması beynin davranışlar ile ilişkisini gösterme yolunda önemli bir adım olmuştur. Diğer yandan bu deney, kas ile beyin arasında herhangi bir bağlantı olmadan kasa uyarı yapıldığında hareketin ortaya çıkabileceğini ve kas kasıldığında hacminde bir artış olmadı̆̆ını göstermiştir (Tarlacı, 2009a).

Willis ve Swemmerdan'ın çalışmalarını Joseph Gall daha da ileriye taşıyarak, beyindeki birçok yapının yanı sıra sinir yollarını ve görme ile oksipital lob arasındaki bağlantıyı saptayarak, beyindeki gri madde ve beyaz madde arasında bir ayrım yapmış ve gri maddenin bir sinir ağı olduğunu göstermiş, beynin ön bölümlerinin dille ilgili olabileceğini ileri sürmüştür. Afazi ile ilgili ilk çalışmaları da Gall yapmıştır (Greenfîeld, 2000; Özakpınar, 2013; Sabbatini, 1997; Tanrıdağ, 1993). Günümüzde nöropsikolojinin temel konusu olan biliş-beyin ilişkisini anlama yolunda yapılan çalışmaların ilk öncüsü Gall'ın çalışmaları olmuştur.

Diğer yandan Gall ve onun öğrencisi olan Johann Spurzheim'in başını çektiği frenoloji akımı, beyni haritalandırmayı ve kişinin kafatasına bakarak zihinsel ve duygusal özelliklerini göstermeyi hedeflemiş ve lokalizasyoncu anlayışın temellerini atmışlardır (Boring, 1950; Karakaş, 2003; Karakaş ve Bekçi, 2003; Karakaş, Kafadar ve Bekçi, 2001; Özakpınar, 2013; Schultz ve Schultz, 2007). Psikoloji tarihinde önemli bir yer tutan lokalizasyon - antilokalizasyon tartışmasının fitilini ilk ateşleyen Gall ve Spurzheim'in çalışmalarıdır. 
Marc Dax'ın bellek ile beynin sol yarıküresi arasında bir ilişki olduğunu, aynı zamanda beynin sol yarıüresinin dil ile de ilgili olduğunu ileri sürmesi, bellek ve dilin beynin hangi bölgesi ile ilişkili olduğu konusundaki araştırmalara ön ayak olmuştur (Ergenç, 2003). Dil ve bellek, günümüzde psikolojinin en önemli çalışma konularındandır. $\mathrm{Bu}$ bağlamda Marc Dax'ın görüşleri, psikoloji bilimi açısından önemlidir.

Francois Magendie ve Charles Bell'in duyu ve hareket sinirleri arasındaki ayrımı keşfetmeleri, nöropsikolojinin gelişimi açısından önemli bir katkı yapmıştır. Onların bulgularına Bell- Magendie yasası ismi verilmiş ve daha sonra bu keşfi, sinirlerde sadece bir yönde iletim olduğu yönündeki bulgu tamamlamıştır (Özakpınar, 2013).

Marshall Hall, bedenin istemli-istemsiz hareketlerinin yanı sıra bilinçli ve bilinçdışı hareketleri arasında bir ayrım yaparak, istemli davranışların serebruma, refleks davranışların omuriliğe, istemsiz davranışların kas sisteminin doğrudan uyarımına ve solunumun da medullaya bağlı olduğunu düşünmüştür (Schultz ve Schultz, 2007; Taylor, 1967'de aktaran, Özakpınar, 2013). Hall'ın çalışmaları beyin- davranış ilişkisi yönünde önemli bulgular sunmuştur.

Sinir sistemi üzerine yapılan çalışmalardan en önemlileri Johannes Müller ve Hermann von Helmholtz'un çalışmalarıdır. Müller, farklı sinirleri etkileyen tek bir uyaranın, bu sinirlere has olan duyumları, aynı siniri etkileyen değişik uyaranların ise ilgili sinire has duyumları ortaya çıkardığını; bir duyu sinirinin uyarılması neticesinde ortaya çıkan sonucun uyaranın biçiminden ziyade duyu organının doğasına bağlı olduğunu bulgulamıştır. Buna, sinirlerin özel enerji yasası adı verilmektedir (Berrios, 2005; Özakpınar, 2013). Helmholtz ise sinir akımının hızı, görme ve işitme algısı ile ilgili çalışmalarıyla psikolojinin bilim olmasına önemli katkılar sunmuştur. Sinir akım hızının çok hızlı olmasından dolayı ölçülemeyeceğine dair inancı kurbağa bacağında yaptığı deneyle yıkmış ve iletinin hızının saniyede seksen üç metre kadar olduğunu ölçmüştür. Bu bulgu, daha önce sanılanın aksine düşünce ve hareketin eş zamanlı olarak ortaya çıkmadığını, ölçülebilir aralıklarla birbirini izlediğini göstermiştir. Bu gözlem, psikolojik süreçlerin ölçülebilir ve üzerinde deney yapılabilir olduğunu gösteren ilk işaretlerden biri olmuştur (Cahan, 1993; Darrigol, 1998; Schultz ve Schultz, 2007).

Bir yanda sinir sistemi üzerinde çalışmalar sürerken diğer yandan beyin-davranış ve beyin bilişsel işlevler (dil, bellek vb. gibi) konusunda çalışmalar yapılmaktayd. Dil üzerine en önemli çalışmaların başında Paul Broca'nın çalışmaları geliyordu. Broca, bedenlerinin sağ tarafına felç inmiş ve konuşulanları anladıkları halde, konuşamayan hastaların otopsilerinde beynin sol yarıküresinin frontal üçüncü kıvrımında lezyonlar tespit etmiş ve hastalardaki konuşma kaybının bu lezyonlardan kaynaklandığını ileri sürmüştür. Broca'nın konuşmanın merkezi olarak nitelendirildiği bu bölüme onun adı verilerek bu alan Broca alanı olarak adlandırılmıştır. Broca, bu bölgedeki lezyonlar sonucu oluşan konuşma kaybını “afemi” olarak adlandırmıştır (Özakpınar, 2013; Tanrıdağ, 1993).

Tipk1 Broca gibi Carl Wernicke de 1874 'de farklı dil problemleri olan hastalar üzerinde araştırmalar yapmıştır. Broca'nın hastalarından farklı özelliklere sahip vakaları tanımlamış ve nörolojide 'sensoryel afazi' kavramının doğmasına vesile olmuştur. Wernicke'nin araştırma yürüttüğü hastalar, aşırı derecede akıcı konuşsalar da anlamsız sözcükler kullanıyorlar ve işitmelerinde herhangi bir problem olmamasına rağmen 
duydukları sözcük dizimlerini anlayamıyorlardı. Bu rahatsızlı̆ga önceleri 'Wernicke afazisi' denilirken, sonraları 'receptive afazi' ismi verilmiştir. Wernicke, konuşma sorunu yaşayan hastaların otopsilerinde, lezyonların sol yarıkürenin temporal lobunun üst ve arka kısmında konumlandığını gözlemlemiştir. Bu bölge, önceden Broadmann'ın 22. kortikal alanı olarak adlandırılırken, artık Wernicke alanı olarak adlandırılmaktadır. Broca ve Wernicke alanları arasında yer alan ve yineleme işlevinden sorumlu kabul edilen 'arkuat fasikülüs' liflerini ilk olarak tanımlayan yine Wernicke olmuştur. O'nun çalışmaları sonucunda Wernicke alanının şifreyi çözdügü̈, Broca alanının ise konuşmanın çıktısını sağladığı anlaşılmıştır (Ergenç, 2000; Tanrıdăg, 1993).

Broca ve Wernicke'den sonra John Huglings Jackson da afezi (söz yitimi) üzerine araştırmalar yapmış ve bu rahatsızlığın sadece bir konuşma bozukluğu olmadığını genel bir zihinsel bozulma sonucu dilin de bozulması olduğunu ileri sürmüştür (Taylor, 1958'den akt. Özakpınar, 2013). Jackson yaptığı çalışmalarla sağ elini kullanan insanlarda afazinin sol beyin yarıküresindeki bir hasarla ilişkili olduğunu göstererek Broca'nın konuşma merkezinin beynin sol yarıküresinde olduğu yönündeki bulgusunu desteklemiştir. Ayrıca, görsel uzamsal yeteneklerin bozulmasının sağ beyin yarıküresindeki hasardan kaynaklandığını ileri sürmüştür (Özakpınar, 2013).

Jackson'un ileri sürdüğ̈̈ görüşler sonradan yapılan çalışmalarla da doğrulanmıştır. Yapılan deneylerde, hayvanların kortekslerinin belirli noktalarına elektrik uyarısı verilince uyarılan bölgelerin sırasına göre birbirinden farklı hareketlerin ortaya çıktığı gözlenmiştir (Young, 1950'den akt. Özakpınar, 2013). Diğer yandan Jackson, beynin patolojik durumlarda kendi uyaranını oluşturarak istem dışı tepkiler doğurabildiğini gözlemlemiştir. Onun bu gözlemi, davranışçlıkta iddia edildiği gibi bütün tepkilere gözlenebilir diş uyaranların neden olduğu düşüncesinin yanlışlığını göstermesi açısından son derece önemlidir. Diğer bir ifadeyle bu gözlem bize, davranışçılığın iddia ettiğinin tersine, içerde işleyen bir sistemin varlığını göstermektedir (Özakpınar, 2013).

Psikolojinin gelişiminde son derece önemli rolü olan bir diğer bilim insanı Pierre Flourens'tir. Flourens, güvercinler ve kurbağalar üzerinde ablasyon (beynin bir parçasının çıkartılması) ve lezyon (beyinde hasar oluşturma/hasarlama) yöntemlerini kullanarak yaptığı araştırmalarda, beynin büyük bir kısmı çıkarılsa bile, geriye kalan parçanın bütün organsal ve ruhsal fonksiyonları üzerine almaya yeterli olabileceğini ve beyin fonksiyonlarının beyine eşit olarak bölündüğünü göstermiştir. Ayrıca beynin motor ve algısal fonksiyonlarının farklı bölümlerde konumlandığını da bulgulamıştır (Solso, 2001; Thorwald ve Ergin, 1996). Diğer yandan Flourens, beynin çeşitli kısımlarını ve omuriliği sistematik olarak tahrip ederek serebrumun yüksek düzey zihinsel süreçleri, orta beynin bölümlerinin görsel, işitsel refleksleri ve beyinciğin koordinasyonunu ve medullanın da kalp atışı, solunum ve diğer yaşamsal işlevleri kontrol ettiğini fark etmiştir (Schultz ve Schultz, 2007). Özetle Flourens, serebral hemisferlerin algılama; medullanın yaşamsal işlevler; beyinciğin (serebellum) denge ve hareketle yani motor aktiviteyi düzenlemekle ilgili olduğu sonucuna varmış fakat belleğin beynin hangi bölümü ile ilişkili olabileceği konusunda bir sonuca varamamıştır. Beyin işlevleri konusunda holistik (bütüncül) yaklaşım sergilemiştir (Pearce, 2009; Yildirim ve Sarikcioglu, 2007).

Schultz ve Schultz (2007), Hall ve Fourens'in bulgularının günümüzde de geçerliliğini koruduğunu ve bu iki bilim insanın beyni incelemede kullandıkları lezyon 
(hasarlama) yöntemi ile de fizyoloji ve psikolojiye büyük katkılar sunduklarını belirtmektedir. Schultz ve Schultz, beynin bir bölümüne zarar verme veya yerinden çıkarma üzerine kurulu olan lezyon yönteminin dışında Broca'nın 1861 yılında kullandığ yöntem ve G. Fritsch ve E. Hitzig'in 1870'da kullandığı elektriksel uyartm (electrical stimulation) yönteminin de diğer önemli deneysel yöntemler olarak fizyoloji ve psikoloji açısından önem teşkil ettiğini ama bu üç yöntem içerisinde en verimli olanının, elektriksel uyarım yöntemi olduğunu belirtir.

Psikoloji tarihinden önemli bir yeri olan bir diğer bilim insanı da Karl S. Lashley’dir. Lashley, beynin kütlesel etkinlikte bulunduğu ve beyin bölgelerinin eşit potansiyelli olduğu ilkelerini ortaya koymuştur. Buna mass action yasası (kütle etkisi) ve eşpotansiyellilik (equipotentiality) yasası denilmektedir. Eşpotansiyelilik yasası, beyin kabuğunun tamamının öğrenme ve bellekten sorumlu olduğunu ve bu sorumluluğun beyinde eşit olarak paylaşıldığını söylemektedir. Lashley, kesip çıkarma yöntemini kullanarak öğrenme, bellek ve zekâ ile beyin bölgeleri arasındaki ilişkiyi göstermeyi başarmıştır (Beach, 1961; Haggbloom ve ark., 2002; Özakpınar, 2013).

Beyin konusunda yapılan araştırmalar, lokalizasyon-antilokalizasyon tartışmasının doğmasına yol açmıştır. Lokalizasyon fikri, beynin belli bölgelerinin belli işlevlerden sorumlu olduğunu savunurken; antilokalizasyon fikri, beynin kütle halinde yani bir bütün olarak çalıştı̆̆ını savunuyordu. Gall, Spurzheim, Broca ve Wernicke gibi bilim insanlarının bulguları lokalizasyon fikrini; Flourens ve Lashley'in bulgularıysa antilokalizasyon fikrini güçlendirmiştir (Boring, 1950; Karakaş, 2003). Bugün, her iki görüşün de haklılık payının olduğu kabul edilmektedir. Farklı bilişsel kusurları olan insanlarla yapılan araştırmalar, görme ve konuşma gibi bazı bilişsel işlevlerin beynin spesifik bölgelerinde lokalize olduğunu gösterirken; düşünme, bellek gibi üst boyuttaki bilişsel işlevlerin ise beynin geneline yayıldığını göstermiştir. Günümüzde, beyinde yalnızca belirli bir işleve adanmış bölgelerin olduğu fakat özellikle üst düzey bilişsel işlevlerde ise beynin bir bütün halinde ve organize bir şekilde çalıştığı bilinmektedir (Parkin, 2000; Solso, 2001; Zangwill, 2009) .

\section{Fizyolojik Çalışmaların Psikolojinin Doğuşuna Etkisi}

Fiziğin, fizyoloji alanına uygulanması neticesinde ortaya çıkan yukarda belirtilen bulgular, psikolojinin bir bilim olmasına giden yolu açmıştır. Fizyolojinin deneysel metotlarını, psikolojinin problemlerine uygulama anlayışını benimseyen Weber, psikolojinin doğa bilimlerine yakın olduğunu düşünmüş ve zihnin deneysel olarak incelenmesi üzerine yapılan çalışmaları desteklemiştir. Weber'in dokunma duyumu üzerinde yaptığı deneylerde ortaya koyduğu "iki nokta eşiği" bulgusu, yeni psikolojinin en önemli kavramlarından biri olan "eşik" kavramının ortaya çıkmasını sağlamıştır. Weber, ağırlıklar arasındaki ayırt edilebilir en küçük farkları, yani ancak fark edilebilir farkları, belirleme üzerine çalışmalar yapmıştır. Gustav Theodor Fechner de Weber'le aynı paralelde bir çalışma yürütmüş ve bu iki bilim insanın bulgularının uyuşması nedeniyle Weber-Fechner yasası ortaya çıkmıştır. $S=K \cdot \log R$ formülü ile ifade edilen bu yasada " $\mathrm{S}$ " duyumun büyüklüğünü, "R" uyarıcının büyüklüğünü gösterirken " $K$ " ise sabit değeri ifade etmektedir. Bu yasa, duyuların şiddetinin uyaran şiddetinin logaritması ile orantılı olduğunu göstermektedir. Fechner, "psikofizik" terimini kullandığ bu çalışmasıyla ruh (zihin)-beden etkileşimini deneysel olarak göstermeyi başarmıştır. Böylelikle psikofizik, psikoloji açısından temel belirleyici bir kavram haline gelmiştir (Fancher, 1997; Schultz ve Schultz, 2007). 
Yukarda belirtilen çalışmasıyla Fechner, deneysel psikolojinin ve psikofiziğin kurucularından biri olma ünvanını elde etmiştir. Fechner'in duyum konusuna olan ilgisinin temelinde, ruh (zihin)-beden etkileşimini niceliksel yönden ispat etme isteği yatmaktaydı. Fechner, felsefecileri bir hayli zamandır meşgul eden ruh (zihin)-beden sorununun çözümünün deneysel ispattan geçtiğini savunmuştur. Bu doğrultuda ruh (zihin) ile bedenin etkileşiminin nasıl ölçülebileceğini düşünürken, ruhsal duyumla maddi uyarıcı arasında niceliksel bir iliş̧i bulunabileceğini fark etmiştir. Fechner, duyum miktarının (ruhsal nitelik), uyarıcı miktarına (fiziksel veya maddi nitelik) bağlı olacağını öngörmüş ve duyumdaki değişikliği ölçmek için fiziksel uyarıcıdaki değişikliğin ölçülmesinin zorunlu olacağını düşünmüştür. Bu düşünce ışığında yaptığı deneyler, uyarıcı yoğunluğunun etkilerinin mutlak olmadığını ve var olan duyumla ilişkili olduğunu, geometrik seri uyarıcıyı nitelendirirken, aritmetik serinin duyumu nitelendirdiğini ortaya koymuştur. Weber-Fechner yasasının özü budur (Schultz ve Schultz, 2007).

Ruh (zihin)-beden sorunu sadece Fechner'in çalışmaları üzerinde değil, duyum üzerine yapılan diğer fizyoloji araştırmalarında da etkili olmuştur (Schultz ve Schultz, 2007). Felsefe tarihine bakıldığında, ruh (zihin)-beden sorununun bilginin kaynağının ne olduğu sorunuyla da doğrudan ilişkili olduğu görülmektedir. Çünkü ontolojik bir sorun olarak ortaya çıkan ruh-beden sorunu, zamanla epistemolojik bir boyut da kazanmıştır (Cevizci, 2010; 2012; Korkman, 2015; 2016; 2017; Tuğcu, 2003; Ural, 2011). "Bilginin kaynağı nedir?" sorusu, Antik Çağ'dan beri filozofların zihnini meşgul etmekteydi (Bayar Bravo, 2007; Cevizci, 2010). Bilginin kaynağının duyumlar vasıtasıyla edinilen deneyimler olduğunu savunan ampirist (görgülcü) fillozofların karşısında, duyumların yanıltıcı olduğunu, doğru ve güvenilir bilgiyi vermediğini savunan rasyonalist filozoflar ise bilginin kaynağının akıl olduğunu düşünüyorlardı. Rasyonalistler, "a priori" (deneyimden önce-önsel) bilgi kavramını ileri sürerken onların karşısında yer alan ampirist (görgülcü) fillozoflar ise doğuştan bilgi diye bir şeyin olamayacağını, insan doğduğunda zihnin "boş bir levha (tabula rasa)" olduğunu savunuyorlardı. Bu iki yaklaşımdan deneysel olarak test edilebilir, ölçülebilir fikir, ampiristlerin fikriydi. Çünkü duyum, ölçülebilir bir kavramdı. A priori kavramını deneysel olarak ölçmek olası görünmüyordu. $\mathrm{Bu}$ nedenle Müller'den, Helmholtz'a, Weber'e, Fechner'e ve Wundt'a kadar uzanan zincirde incelenen konu duyum olmuştur. Nitekim Fechner, ruh ile bedenin etkileşimini deneysel yolla gösterebilmenin yolunun duyumu incelemekten geçtiğini fark etmişti. Çünkü duyum, hem ruh (zihin) ile hem de beden (duyu organları) ile ilişkiliydi. Zihnin deneysel olarak ölçülemeyeceği yönündeki hakîm fikrin aksine Weber-Fechner yasası, Müller'in sinirlerin özel enerji yasası ve Helhmoltz'un sinir iletim hızı ve duyu organlarının uyarılması sonucu oluşan motor tepki süresini ölçmesi, duyumların deneysel olarak çalış1labileceğini göstermiştir. Sinir sistemi ve duyumlar üzerine yapılan deneyler, insan zihninin deneysel olarak araştırabileceğini göstermesi açısından çok önemli bir yere sahiptir. Bu deneyler, Wundt'un 1879'da duyumlar üzerine yaptığı deneye ilham olmuş ve psikolojinin bilim olma kimliğine kavuşmasına önemli bir katkı sunmuştur (Boring, 1950; Karakaş, 2003; Karakaş ve Bekçi, 2003; Karakaş, Kafadar ve Bekçi, 2001; Korkman, 2015; 2016; 2017; Özakpınar, 2013; Schultz ve Schultz, 2007).

Wundt, yaptığı çalışmayla psikolojiyi bir bilim olma kimliğine kavuştursa da onun yapısalcı ekolünü ve bu ekolün kullandığı içe bakış yöntemini bilimsel olmadığı gerekçesi ile John B. Watson ciddi bir şekilde eleştirmiştir. Watson, psikolojinin gözlenebilir ve test edilebilir veriler üzerine çalışması gerektiğini savunuyordu. Watson'a göre Wundt'un 
yöntemi deneysel değildi, dolayısıyla nesnel değil özneldi. Çünkü Wundt, gözlenebilir bir olgu olmayan zihni inceliyordu. Oysa psikolojinin konusu gözlenemeyen bir şey olan zihin değil, gözlenebilir olan davranış olmalıydı. Watson'un bu düşüncesinin en büyük nedenlerinden biri, Pavlov'un klasik koşullanma konusundaki deneysel bulgularıydı. Rus bilim insanı İvan Petroviç Pavlov'un öğrenmenin koşullanmışlık ile bağını göstermesi, davranışç11ık ekolünün doğuşuna zemin hazırlamış ve psikolojinin ilgisinin öğrenme üzerine kaymasına neden olmuştur (Boring, 1950; Özakpınar, 2013; 2014; Schultz ve Schultz, 2007; Zangwill, 2009).

Diğer yandan giriş bölümünde anlatılan Descartes ve La Mettrie'nin ileri sürdükleri bedenin bir makine gibi çalıştığı fikrinin deneysel olarak test edilmesine en çok emeği geçen bilim insanının Pavlov olduğu söylenebilir. Bedenin bir makine gibi çalışmasına yönelik ileri sürülen temel kavram olan "refleks arkı", duyusal uyarıcıların beyine taşındığı ve buradan uygun nöral talimatlar sayesinde ise kaslara ve diğer organlara gönderildiğini ileri sürüyordu. Refleks arkının insan düşünce, duygu ve davranışlarının karmaşık kalıplarının temeli olabileceğini göstermeye çalışan ilk kişi Pavlov olmuştur (Harré, 2015).

Pavlov'un çalışmaları, psikofizyoloji ve deneysel psikoloji alanları üzerindeki önemli bir etki yarattığından Pavlov, her iki bilim dalının da kurucuları arasında gösterilmektedir (Akpur, 2011; Alıc1, 2010; Schultz ve Schultz, 2007). Pavlov, öğrenmenin nörobiyolojik temelleri üzerine yapılan çalışmaların da yolunu açmıştır. Günümüzde yapılan çalışmalarda, öğrenme esnasında nöronlarda yeni aksonların yani yeni sinaptik bağların oluştuğu gözlenmekte ve öğrenme, biyokimyasal bir değişme olarak açıklanmaktadır. $\mathrm{Bu}$ bağlamda öğrenmenin nörokimyasal yapısı konusunda araştırmalar yapılmış ve nörobiyolojik mekanizması konusunda önemli bulgulara ulaşılmıştır (Alıcı, 2010; Barnes, 2014). Nitekim günümüzde öğrenme, bellek, davranış, duyum ve algı gibi bilişsel sistemin öğelerini teşkil eden olguları anlamak için beyinle ilgili çalışmalar yoğunlaşmıştır. Ruhbeden sorunu olarak başlayıp zamanla zihin-beden, bilinç-beden ve en son günümüzde bilişbeyin sorununa evrilen arayış, psikolojinin temel konusudur (Boring, 1950; Karakaş, 2003; Karakaş ve Bekçi, 2003; Karakaş, Bekçi ve Irak, 2003; Karakaş, Kafadar ve Bekçi, 2001). Artık günümüzde beynin bilişi nasıl ortaya çıkarttığını anlamanın yolunun nöronlar ve gliaların nasıl çalıştığını anlamaktan geçtiği genel kabul gören bir yaklaşımdır (Barnes, 2014; Koob, 2011). Eskiden ruh (zihin)-beden sorunu ele alınırken monistik ve düalistik olmak üzere iki temel yaklaşım belirmişti. Monistik yaklaşım, kendi içinde 'panpsişizm' ve 'materyalizm' olmak üzere ikiye ayrılmaktadır. Panpsişizm, ruhu (zihni) kabul edip bedenin varlığını kabul etmemektedir. Materyalizm, bedeni kabul edip ruhu kabul etmemektedir. Düalist yaklaşım ise 'psikofizik paralelcilik' ve 'psikofizik etkileşimcilik' olmak üzere ikiye ayrılır. Psikofizik paralelcilik, ruhun da bedenin de varlığını kabul eder ama ruh ile bedenin iki ayrı, farklı yapı olduğunu ve bu ikisi arasında bir etkileşim olmadığını savunurken, psikofizik etkileşimcilik ise, ruh ile bedenin birbirilerini etkilediklerini savunmuştur (Boring, 1950; Karakaş, 2003; Karakaş ve Bekçi, 2003; Karakaş, Bekçi ve Irak, 2003; Karakaş, Kafadar ve Bekçi, 2001). Karakaş, Bekçi ve Irak (2003) ve Churchland (2012), günümüzdeki bilimsel verilerin her ne kadar psikofizik etkileşimcilik görüşünü desteklese de beyin üzerine yapılan çalışmalar ilerledikçe ve biliş-beyin ilişkisi net bir şekilde anlaşıldıkça, materyalizm görüşünün ağırlık kazanmasının kuvvetle muhtemel olduğunu ileri sürmektedirler. Nitekim Hameroff (1998), Hameroff ve Penrose (1996), Hameroff ve ark. (2002), Penrose (2004a, b, c) ve Tarlacı (2009a ve 2009b), biliş-beyin ilişkisinin sadece fizyoloji ile değil aynı zamanda fizik ve matematikle çözülebileceğini, özellikle kuantum 
fiziğinin bilişsel sistemi anlamada önemli bir rol üstelenebileceği görüşünü ileri sürmektedirler. Bu çerçevede Hameroff ve Penrose'un bilincin oluşumunda mikrotübüllerin önemli bir rolü olduğunu kuantum fiziğine dayanarak ispatlama girişimleri bilim dünyası tarafindan dikkatle izlenmektedir. Belki de ileride Karakaş, Bekçi ve Irak (2003)'ın söylediği gibi şizofreni, depresyon vb. gibi psikiyatrik rahatsızlıklar bir formülle açıklanabilecek düzeye gelecektir.

\section{Sonuç}

Psikoloji, bir yanıyla felsefe ile diğer yanı ile de pozitif bilimlerle sürekli bağı olan bir alandır. Kökenini ruh (zihin)-beden sorunundan alması nedeniyle felsefe ile bağı varken, bilişsel işlevlerin beyin ile ilişkili olmasının deneysel olarak gösterilmesiyle de pozitif bilimlerle bağı vardır. Antik Yunan'da arkhe problemi ile başlayan ontolojik arayışın zamanla bilginin kaynağı konusundaki arayışla ilişsilenmesi, ilk meyvesini Descartes'in ruh (zihin)-beden sorunu konusunda geliştirdiği düşüncelerde vermiş ve ruh (zihin)-beden sorununun çözümlenmesi psikolojinin felsefik altyapısını oluşturmuştur. Diğer yandan fizyolojik çalışmaların zihnin soyut bir mekanizma değil, sinir sistemi ve beyin ile doğrudan ilişkili somut bir mekanizmanın, yani organizmanın, bir ürünü olduğunu göstermesi psikolojinin pozitif bilim kanadında yer alması gerektiği düşüncesini doğurmuştur. Nitekim yukarda belirtilen tüm fizyolojik çalışmalar, psikolojinin sosyal bilim olma yolunda ilerleyerek bilim kimliğine kavuştuğunu değil, tam tersine pozitif bilim olarak tasavvur edilmesi ile bilim kimliğine kavuştuğunu açıkça göstermektedir. Psikolojinin duyum, alg1, bellek, öğrenme, zekâ gibi bilişsel işlevleri incelemesi nedeniyle zor bir işe soyunduğu giriş bölümünde belirtilmişti. Psikolojinin ele aldığı konular, beynin en üst ürünü olan bilincin öğeleridir. Beyin anlaşılmadan bilincin (bilişin) anlaşılması olası görünmemektedir. Yukarıda anlatılanlarda da görüldüğü üzere psikolojiyi fizik, kimya ve biyolojiden ayrı düşünmek olanaksızdır. Bilinç (biliş), somut bir mekanizma olan bedenin bir parçası olan beynin bir ürünüdür. Bu bağlamda çalıştı̆̆ konuların biyolojik, fiziksel ve kimyasal ilkelerinin matematiksel olarak ortaya konulmasından ayrı düşünülmesinin imkânsız olması nedeniyle psikolojinin sosyal bir bilim değil, pozitif bir bilim olması doğası gereği bir ihtiyaç değil, zorunluluktur.

\section{Kaynaklar}

Akpur, U. (2011). "Ivan Pavlov”, İstanbul: Say Yayınları.

Alıcı, T. (2010). "Öğrenmenin Bilimsel Temelleri”, Ankara: Palme Yayıncılık.

Andreassi, J. (1995). "Psychophysiology: Human Behavior and Physiological Pesponse", Third Edition. Hillsdale, NJ: Lawrence Erlbaum.

Azmitia, E.C., Defelipe, J., Jones, E.G., Rakic, P. And Ribak, C.E. (2002). "Progress in Brain Research: Changing Vievs of Cajal's Neuron", Elsevier, New York: Elsevier Science.

Barnes, J. (2014). “Temel Biyolojik Psikoloji” (Çev. Editörü A. Altındağ), Ankara: Nobel Akademik Yay.

Bayar Bravo, I. (2007). “Antikçağda Varlık ve Bilgi Problemleri Üstüne”, FLSF (Süleyman Demirel Üniversitesi Felsefe Bölümü Dergisi), 4: 43-58.

Beach, F.A. (1961). "Karl Spencer Lashley 1890-1958", Washington, D.C: National Academy of Sciences: 9.

Berrios, G. E. (2005). "On the fantastic apparitions of vision by Johannes Müller", History of Psychiatry, 16: 229-246 
Boring, E.G. (1950). “A History Of Experimental Psychology (Second Edition)”, New York: Century.

Bresadola, M. (1998). "Medicine and science in the life of Luigi Galvani (1737-1798)", Brain Research Bulletin, 46(5): 367-380.

Cahan, D. (1993). "Hermann von Helmholtz and the foundations of nineteenth-century science", Berkeley.

Can, N. (2009). "Mekanistik Evren Anlayışı ya da Hakikatin Bilgisinden Fenomenler Bilimine", Kaygl, 13: 101-112.

Cevizci, A. (2012). "Bilgi Felsefesi", 2. Bask1, İstanbul: Say Yayınları.

Cevizci, A. (2010). "Felsefe Tarihi: Thales'ten Baudrillard'a", 2. Basım, İstanbul: Say Yayınları.

Churchland, P.M. (2012). "Madde ve Bilinç: Zihin Felsefesine Güncel Bir Bakış", (Çev. B.Ersöz), İstanbul: Alfa Yayınları.

Clarke, E. and Jacyna, L.S. (1987). "Nineteenth-Century Origins of Neuroscientific Concepts", Los Angeles, CA: University of California Press.

Darrigol, O. (1998). "From organ pipes to atmospheric motion: Helmholtz on fluid mechanics", HSPS, 29: 1.

Descartes, R. (2014). "Ruhun Tutkuları", (Çev. M. Erşen), İstanbul: Say Yayınları.

Ergenç, İ. (2000). "Dilin Beyindeki Organizasyonu ve Konuşmanın Gerçekleşmesi: Multidisipliner Yaklaşımla Beyin ve Kognisyon", Ankara: Çizgi Tıp Yayınevi.

Fancher, R.E. (1997). "Ruhbilimin Öncüleri”, (Çev. A. Yardımlı), İstanbul: İdea Yayınevi.

Finger, S. (1994). "Origins of Neorusience: A History of Explorations into Brain Function", New York: Oxford University Press.

Greenfield, S. (2000). “İnsan Beyni”, (Çev. B. Çekmece), İstanbul: Varlık Yayınları.

Haggbloom, S.J.; Warnick, J.E., Jones, V. K., Yarbrough, G.L., Russell, T.M., Borecky, C.M., McGahhey, R . (2002). "The 100 most eminent psychologists of the 20th century", Review of General Psychology, 6 (2): 139-152. doi:10.1037/1089-2680.6.2.139.

Hamerof, S (1998). "Quantum computation in brain microtubules? The Penrose-Hameroff 'Orch OR' model of consciousness", Philosophical Transactions of the Royal Society A., 356: $1869-1896$.

Hameroff, S., Penrose, R. (1996). "Orchestrated reduction of quantum coherence in brain microtubules: A model for consciousness", Mathematics and Computers in Simulation, 40: 453-480.

Hameroff, S., Nip, A., Porter, M., Tuszynski, J. (2002). "Conduction pathways in microtubules, biological quantum computation, and consciousness", BioSystems, 64: $149-168$.

Harré, R. (2015). "Psikolojide Temel Düşünürler (Çev. Ed. H. Harlak)”, İstanbul: Sentez Yayınc1lik.

Karakaş, S (2003). "Beden-Zihin Sorunundan Beyin-Biliş İlişkisine: Felsefeden Pozitif Bilimlere”, (Karakaş, S., İrkeç, C., Yüksel, N. (Ed.) (2003). Beyin ve Nöropsikoloji (1.Bölüm)). Ankara: Çizgi Tıp Kitabevi: 3-29.

Karakaş S. ve Bekçi B. (2003). "Zihin/Davranış İle Beden/Organizma İlişkilerini Ele Alan Bilim Dallarının Doğuşu ve Gelişimi”, NeuroQuantology, 2: 35-55.

Karakaş, S., Bekçi, B. Ve Irak, M. (2003). "Nöropsikoloji, Nöropsikolojik Testler, Ülkemizdeki Durum” (Karakaş, S., İrkeç, C., Yüksel, N. (Ed.) (2003), Beyin ve Nöropsikoloji-Bölüm 17). Ankara: Çizgi Tıp Kitabevi: 214-232.

Karakaş, S., Kafadar, H., Bekçi, B. (2001). "Beyin Zihin İlişkisinde Büyük Düşünürler ve Kuramlar: Pozitif Bilim Dalları İçin Doğurgular”, Nöropsikiyatri Arşivi, 38 (1):15-23. 
Kipnis, N. (1987). "Luigi Galvani and the debate on animal electricity, 1791-1800", Annals of Science, 44: 107-142.

Koob, A. (2011). "Düşüncenin Kökeni: Beynimiz Nasıl Çalışır?”, (Çev. N. Güngör), İstanbul: Alfa Yayınları.

Korkman, H. (2015). “İlkçağ’dan Başlayarak Bilimsel Düşüncenin Gelişim Seyri İçerisinde Psikolojinin Yeri”, Asian Journal Of Instruction - Asya Öğretim Dergisi, 3(1): $1-20$.

Korkman, H. (2016). “Antik Felsefede Psikolojinin Artalanı”, 21. Yüzyılda Eğitim Ve Toplum Dergisi, 5(15): 363-382.

Korkman, H. (2017). "Psikolojinin Tarihsel Artalanı", Ankara: Akademisyen Yayınları.

Ochs, S.A. (2004). "History of Nerve Functions: From Animal Spirits to Molecular Mechanisms", New Yor: Cambridge University Press.

Özakpınar, Y. (2014). "Psikolojinin Kavramsal Yapısı”, 2. Basım, İstanbul: Ötüken Neşriyat.

Özakpınar, Y. (2013). "Psikoloji Tarihi”, 2.Basım, İstanbul: Ötüken Neşriyat.

Parkin, J. A. (2000). “Essential Cognitive Psychology”, USA: Psychology Press.

Pearce, J. M. S. (2009). "Marie-Jean-Pierre Flourens (1794-1867) and cortical localization", European Neurology (Switzerland), 61(5): 311-314. doi:10.1159/000206858. PMID 19295220.

Penrose, R. (2004a). Kralın Yeni Usu I: Bilgisayar ve Zekâ (çev. T. Dereli). Ankara: TÜBİTAK Popüler Bilim Kitapları.

Penrose, R. (2004b). Kralın Yeni Usu II: Fiziğin Gizemi (Çev. T. Dereli). Ankara: TÜBİTAK Popüler Bilim Kitapları.

Penrose, R. (2004c). Kralın Yeni Usu III: Us Nerede (Çev. T. Dereli). Ankara: TUBITAK Popüler Bilim Kitapları.

Piccolino, M. (1997). "Luigi Galvani and animal electricity: Two centuries after the foundation of electro-physiology", Trends Neurosci., 20: 443-448.

Sabbatini, R. M.E (1997). "Phrenology: the History of Brain Localization", Brain and mind.

Schultz, D.P. \& Schultz, S.E. (2007). "Modern Psikoloji Tarihi”, 2. Baskı, (Çev. Y. Aslay), İstanbul: Kaknüs Yayınları.

Shepherd, G.M. (1991). "Function of the Neuron Doctrine", New York: Oxford University Press.

Solso, R. R. (2001). “Cognitive Psychology”, USA: Allyn and Bacon.

Tanrıdağ, O.(1993). "Afazi”, 2.Baskı, Ankara: GATA Basımevi.

Tarlacı, S. (2009a). "Bilinç, Antik Çağdan Bilincin Yeniden Keşfine", İzmir.

Tarlacı, S. (2009b). "Kuantum Beyin: Bilinç-Beyin Sorununa Yeni Bilimsel Yaklaşım", İzmir

Tuğcu T. (2003). "Batı Felsefesi Tarihi”, 4. Basım, Ankara: Alesta Yayınları.

Ural, Ş. (2011). "Bilim Tarihi”, 8. Bask1, İstanbul: Çantay Kitabevi.

Yildirim, F. B. and Sarikcioglu L. (2007). "Marie Jean Pierre Flourens (1794-1867): An extraordinary scientist of his time". J. Neurol. Neurosurg. Psychiatr. (England), 78(8): 852. doi:10.1136/jnnp.2007.118380. PMC 2117745. PMID 17635978.

Zangwill, O.L. (2009). "Modern Psikolojinin Gelişimi”, (Çev. Y.Özakpınar), İstanbul: Ötüken Neşriyat.

Zengeroğlu, S.A ve Nalçacı, E. (2015). "Santiago Ramòn y Cajal ve Nöron Doktrini”, Turk J. Neurol., 21: 81-84. 